\title{
Csatahajók lokátorral megvívott éjszakai tengeri ütközete Guadalcanalnál 1942-ben rrasz
}

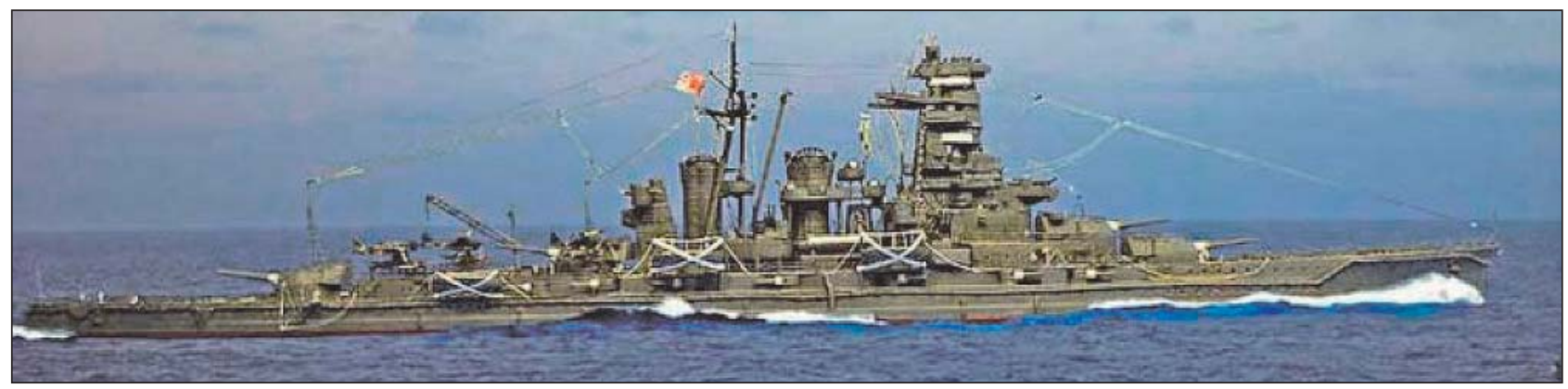

1. ábra. A KIRISHIMA csatacirkáló 1937-es állapotában

\section{TECHNIKAI ELŐZMÉNYEK}

A távoli objektumok helyzetét az időjárástól és a napszaktól függetlenül meghatározni tudó, rádióhullámokkal működő távolságmérő berendezés, Christian Hülsmeyer (Huelsmeyer) 1904-ben bejegyzett találmánya továbbfejlesztését majdnem egyszerre kezdték el a legfejlettebb ipari országokban. A huszadik század harmincas éveire ért el odáig a technológia fejlettsége, hogy a radar - radio detection and ranging - megvalósítása valóban kivitelezhető ötletnek tűnt. Az angol, német, olasz, francia és japán radarfejlesztések mind 1932 és 1936 között indultak el, egymástól majdnem függetlenül.

Az Egyesült Államok 1935-től (az első radar megrendelési dátuma 100 ezer dollárért) kiemelt kutatási területként kezelte a radar fejlesztéseket. [1] A haditengerészet kutatóintézetének rádiótechnológiával foglalkozó részlegét Dr. Hoyt Taylor vezette. Taylor, illetve két munkatársa, Leo Young, és Robert Morris Page 1932-re el is készítették az első berendezést, amely már érzékelni tudta a repülőgépeket. ${ }^{1}$

A rögzített antennákkal rendelkező készülék még nem volt igazi radarnak tekinthető, de a fejlesztés innen már töretlenül haladt előre. Young ötlete nyomán áttértek a rövid idejű impulzus jelek alkalmazására, a visszaverődő jeleket pedig két kisugárzás között fogták. Az 1934 márciusában elkészült első, $60 \mathrm{MHz}$-en múködő készüléknél az adási idő 10 mikroszekundum volt, a két kisugárzott jel

ÖSSZEFOGLALÁS: Az első amerikai impulzus-üzemű radar 1936-ban 25 mérföldes $(40 \mathrm{~km})$ távolságról tudta érzékelni a repülőgépeket. Ugyanabban az évben egy új találmány, az adás-vétel kapcsoló segítségével sikerült ugyanazzal az antennával megoldani a jelek sugárzását és vételét is. Az első amerikai hajófedélzeti radart 1939-ben szerelték fel a NEW YORK és TEXAS csatahajókon. 1940-től hatalmas összegeket költöttek el az e területen zajló fejlesztésekre. Számos új radar-technológiát a britek adtak át szövetségesüknek. A hajófedélzeti radarok fejlesztésében az Egyesült Államok 1942-re így előnyre tett szert. A radar alkalmazása terén megszerzett amerikai előny azután jelentős mértékben befolyásolta a háború tengeri ütközeteinek kimenetelét.

KULCSSZAVAK: haditengerészet, II. világháború, csatahajó, radar, légtérfigyelő lokátor közti vételi idő pedig 90 mikroszekundum, amely kb. 2 km és 13,5 km között tette lehetővé a nagy visszaverő felülettel rendelkező repülőgépek detektálását.

A továbbfejlesztett radarkészüléket 1936 júniusában mutatták be kormányzati tisztviselőknek és a haditengerészet képviselőinek. A bemutató során 25 mérföld $(40,2$ km) távolságról is sikerült bemérni egy repülőgépet. A képviselők elégedettek voltak a látottakkal, és további támogatásukról biztosították a programot. A biztató eredmények nyomán a szenátus 100 ezer dollárt különített el a további kutatásokra, amelyek a legmagasabb prioritású fejlesztések közé kerültek, és ugyanekkor egyben titkosították is őket.

Ezzel elkezdődött a hajófedélzeti használatra alkalmas radar kifejlesztése. Az antennarendszerek nagyságának hajókon is használható méretre csökkentéséhez rövidebb hullámhosszt választottak, a korábbi $5 \mathrm{~m}$-es $(60 \mathrm{MHz})$ helyett 1,5 métereset $(200 \mathrm{MHz})$. A radarberendezések méretét tovább csökkentette, hogy az adás-vétel kapcsoló (egyszerű szikraköz, amely adáskor rövidre zárta a vevő bemenetét) segítségével sikerült ugyanazzal az antennával megoldani a jelek sugárzását és vételét, addig ugyanis ehhez két külön antennát használtak.

Az első hajófedélzeti radart 1937 áprilisában próbálták ki, és mutatták be a tengerészet képviselőinek. 1939-re a haditengerészeti radar több változata is elkészült, amelyeket a Karib-tengeren próbáltak ki, a NEW YORK és TEXAS csatahajókon. A legjobbnak a másfél méteres hullámhoszszon működő, XAF jelű készülék bizonyult, amely ideális

ABSTRACT: In 1936, the first American pulsed radar was capable of detecting aircraft from a distance of 2.5 miles (4 kilometres). In the same year, using a new invention - a transmit/receive switch - is became possible to send and receive the signals with the same antenna. The first American shipborne radar was installed on the battle ships NEW YORK and TEXAS. From 1940 , enormous sum of money was spent on development in this field. Several pieces of new radar technology was handed over by the British to their ally. By 1942, the United States obtained advantage in development of ship-borne radar in such a way. Then, advantage obtained by the American in use of radar influenced outcome of the naval engagements of the war significantly.

KEY WORDS: navy, World War II, battleship, radar, air surveillance radar 


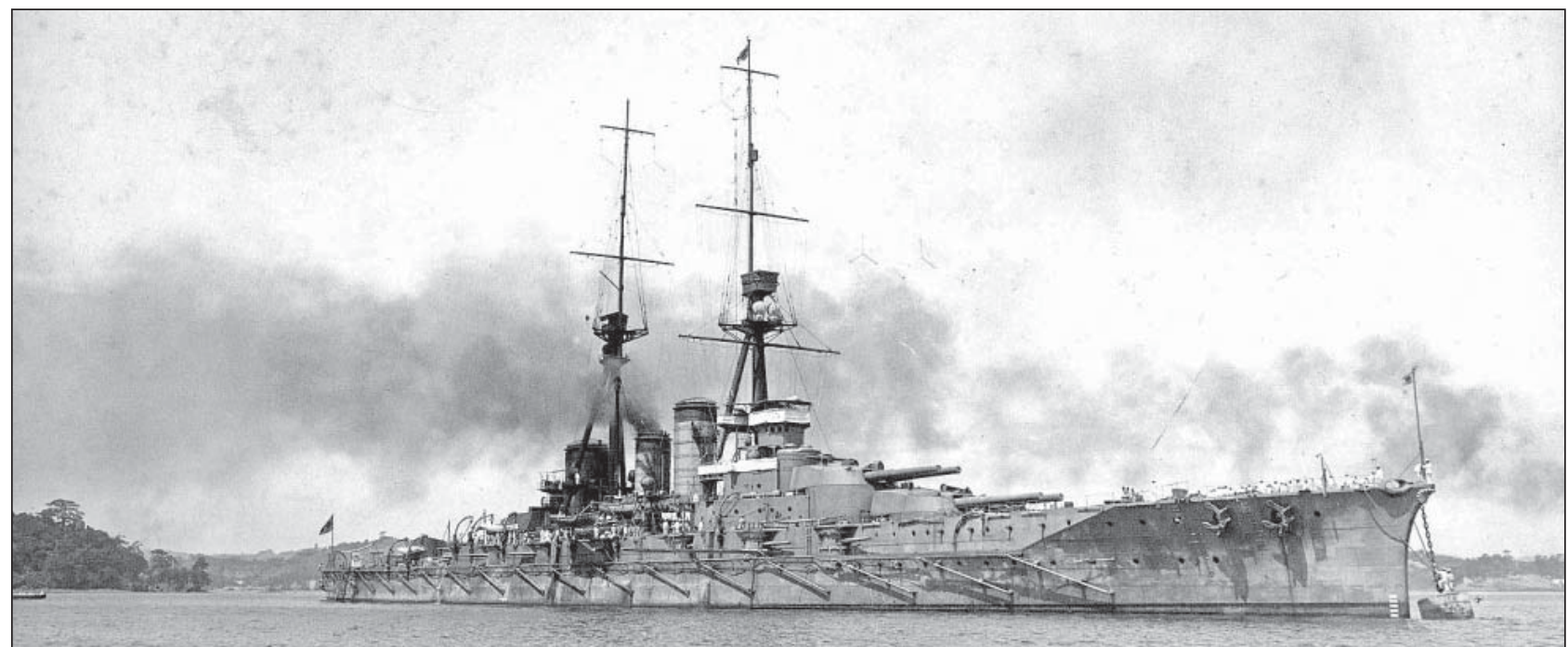

2. ábra. A HARUNA csatacirkáló 1916-ban, eredeti állapotában

körülmények között akár 50 mérföldes $(80$ km) távolságról is képes volt észlelni a repülőgép-kötelékeket. A NEW YORK kapitánya annyira fellelkesült az új berendezés képességei láttán, hogy jelentésében azt tanácsolta, azonnal szereljenek fel minden anyahajót ilyen készülékekkel.

Az első hat, katonai használatra már valóban alkalmas radarkészüléket 1940 májusában szállították le a haditengerészetnek. A CXAM jelű légtérfigyelő radar - a XAF továbbfejlesztése - $75 \mathrm{~cm}$-es hullámhosszon dolgozott, 15 kW kimenő teljesítménnyel. A nagy magasságon repülő gépeket már 70 mérföld $(112,6 \mathrm{~km})$ távolságból is képes volt észlelni, míg a nagy felszíni hajókat 16, a kisebbeket 12 mérföldről (27,7, illetve 19,3 km). Ezek a radarok még túl nagyok és nehezek voltak ahhoz, hogy nehézcirkálónál kisebb hadihajókon is használni tudják őket, de már fejlesztés alatt volt a kisebb méretü, de nagyobb kimenő teljesítménnyel dolgozó SA radar is, amelynek próbaüzemét 1941 júliusában végezték a SEMMES rombolón. Az US Navy hajóin 1942-tól ennek a radarnak a tökéletesített változatai, az SC, majd az SK jelű keresőradarok kerültek rendszeresítésre, légtérfigyelő radarként.

A nagy antenna-nyalábszélesség miatt a keresőradarok nem voltak elég pontosak ahhoz, hogy tűzvezetésre használják őket. A tűzvezető radarok feladata, hogy a keresőradar által már felderített célpontok mozgását kövessék, hasonlóan az optikai távolságmérőkhöz. A tűzvezető radarok antennáit éppen ezért rendszerint fizikailag összekapcsolták az optikai távolságmérőkkel. A mérési pontosság növeléséhez, a keresőradarok által használt frekvenciát tovább kellett csökkenteni a mikrohullámú tartományig. Ezáltal növelhetővé vált az adóteljesítmény, csökkenthetők lettek az antennaméretek, növelhető az antennanyereség és az

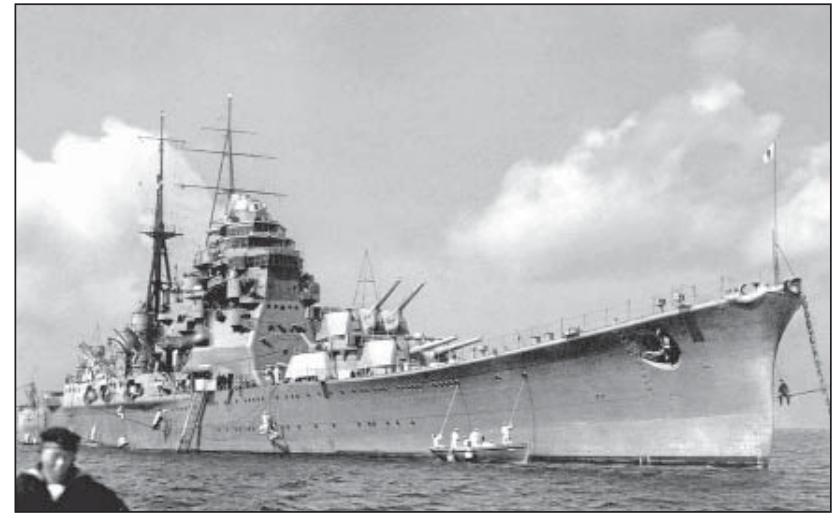

4. ábra. A TAKAO nehézcirkáló 1930-ban

antenna irányélességi szöge. A fejlesztéseknek lendületet adott, amikor 1940-ben az angolok megosztották kutatási eredményeiket az amerikaiakkal és átadták az általuk használt radartechnológiát, így a „cm”-s hullámtartományban üzemelő magnetront. A britek a radarok fejlesztésének egyes területein megelőzték az amerikaiakat.

Az első mikrohullámú radarok fejlesztése 1940 áprilisában kezdődött a Bell Telephone Laboratories kutatóintézetében, és egy évvel később már el is készültek az első prototípusok. Az FA - később Mark 1- jelü, 40 cm-es hullámhosszon dolgozó radarok tovább fejlesztésével könnyü és kisméretű radarokat állítottak elő, amelyek már felszerelhetők voltak kisebb hadihajók felépítményére is, a még későbbi változatokat pedig akár már repülőgépeken is használhatták. ${ }^{2}$

\section{3. ábra. A HARUNA csatahajó 1934-ben, az első átépítések után}

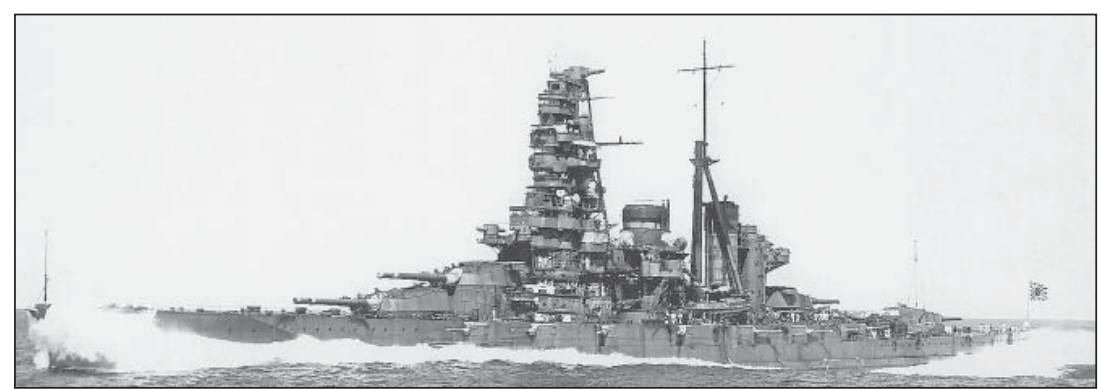

Az új, katódsugárcsöves kijelzőkkel felszerelt mikrohullámú radarokkal az angol-amerikai készülékek 1941-re már sokkal magasabb műszaki színvonalat képviseltek, mint a hasonló japán vagy német eszközök. Ezek a radarok már nem egyszerüen csak felderítésre és előrejelzésre voltak használhatóak, hanem elég pontosak voltak ahhoz is, hogy az általuk szolgáltatott adatok alapján irányítsák célra a hadihajók ágyúit. $A z$ új berendezések rövidesen a gyakorlatban is bizonyíthatták képességeiket. 


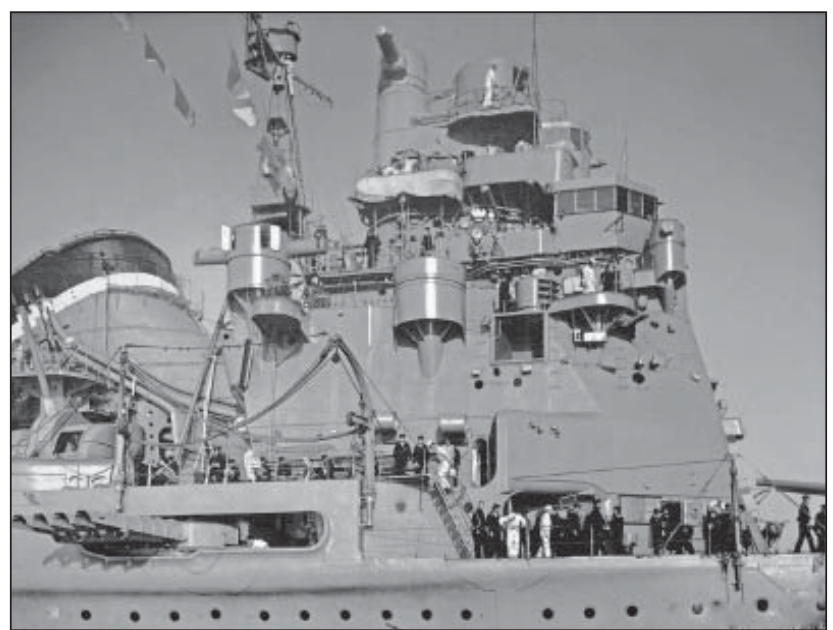

5. ábra. A TAKAO nehézcirkáló parancsnoki tornya

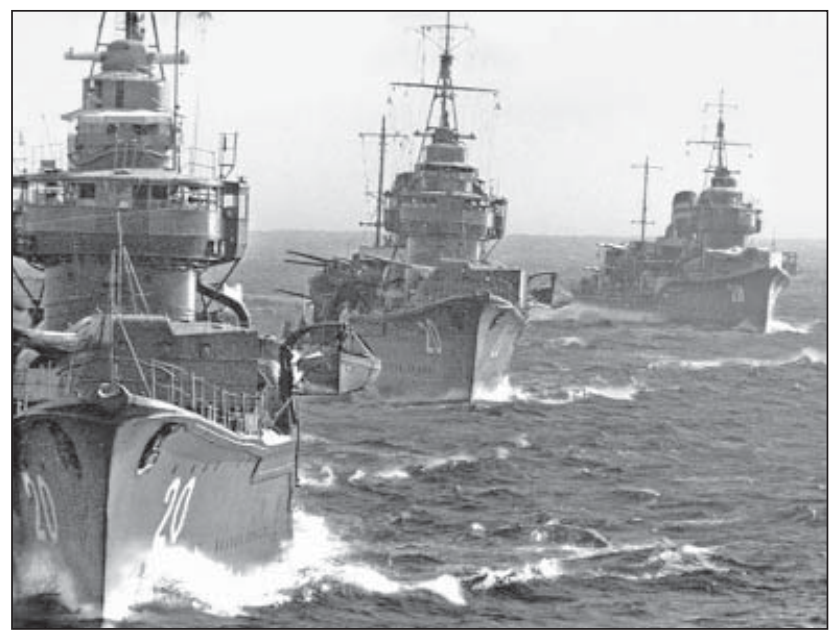

6. ábra. Japán rombolók egy háború előtti hadgyakorlaton

\section{AZ AMERIKAI HAJÓFEDÉLZETI LÉGTÉRFIGYELŐ RADAROK ELSŐ HARCI ALKALMAZÁSA}

A Csendes-óceáni hadszíntéren Pearl Harbornál sor került az első amerikai légtérfigyelő radarok alkalmazására. A hadsereg Opana-hegyen települt lokátorállomása már 136 mérföld $(219 \mathrm{~km})$ távolságról észlelte a közeledő japán repülőgépeket, a radarkezelők figyelmeztetéseit azonban senki sem vette komolyan. A hadsereg és a flotta tisztjei a radart általában kísérleti jellegű, kétes megbízhatóságú eszköznek tekintették, és még hosszú időbe tellett, mire kiismerték, és a gyakorlatban is alkalmazni tudták a benne rejlő lehetőségeket.

A következő hónapok tengeri ütközetei során a légtérfigyelő radar jó szolgálatot tett a US Navy hadihajóinak, azonban még akkor is csak előrejelző szerepet töltött be, figyelmeztette a hajókat a támadó japán repülőgépek közeledésére. A tengeri ütközetek szinte kizárólag a repülögép-hordozókon települt repülőgépek összecsapásaiból álltak, felszíni hadihajók közötti tűzharcra - amelyben az ekkortájt rendszeresített tűzvezető radarokat is használni tudták volna - még nem került sor.

Pearl Harbor után nyolc hónappal a US Navy parancsnoksága úgy érezte, a haditengerészet már eléggé magához tért ahhoz, hogy ellentámadást indítson, és felhagyjon az addigi védekező taktikával. A flotta vezérkari főnöke, Ernest King tengernagy, a támadó hadmüveletre a Salamon-szigeteknél látott jó lehetőséget. A japánok néhány hónappal korábban szállták meg a szigeteket, hogy bekerítsék, és elszigeteljék Ausztráliát. A szigeteken csak kis számú helyőrséget állomásoztattak, visszafoglalásuk tehát könnyű feladatnak ígérkezett.

A hadművelet célpontjai kezdetben Tulagi, és a Santa Cruz-szigetek voltak, ám az előkészületek közben az amerikaiak tudomást szereztek róla, hogy a japánok Guadalcanal szigetén repülőtér építésébe fogtak. Miután az itt létesítendő japán légitámaszpont veszélyeztette az Ausztrália felé vezető útvonalakat, az eredetileg Santa Cruz megszállására szánt csapatokat végül Guadalcanalhoz irányították át.

A partraszállásra 1942. augusztus 8-án került sor. A rossz időben sikerült észrevétlenül megközelíteni a szigeteket, így a japán csapatokat meglepetésként érte a támadás. $\mathrm{Az}$ amerikaiak viszonylag csekély veszteségekkel, két nap alatt elfoglalták Tulagit, a guadalcanali helyőrséget pedig a sziget belsejébe szorították vissza.

A már majdnem kész repülőteret így végül az amerikaiak fejezték be augusztus 18-án, és azt a tengerészgyalogság egyik Midwaynél elesett pilótája után Henderson Field-nek nevezték el. Az idetelepült repülőgépek nappal komoly veszélyt jelentettek a hajókra, ezért a japánok a lassú teherhajók helyett a gyors rombolókkal szállították az erősítést és az utánpótlást, amelyek a közeli szigetekről egy éjszaka alatt meg tudták tenni az utat Guadalcanalig, és vissza. A rombolók azonban csak a csapatok, és az élelmiszer utánpótlását tudták úgy-ahogy biztosítani, ágyúkat és járműveket ezekkel nem tudtak szállítani.

A US Navy hajói természetesen igyekeztek elvágni a japánok utánpótlási vonalait, s a következő hetekben egy sor összecsapásra került sor a japán és az amerikai cirkálók és rombolók között. ${ }^{3} \mathrm{Az}$ éjszakai harcokban egyértelműen a japánok voltak az eredményesebbek, és súlyos veszteségeket okoztak az amerikai erőknek.

\section{7. ábra. Az AYANAMI romboló 1939 előtti képe}

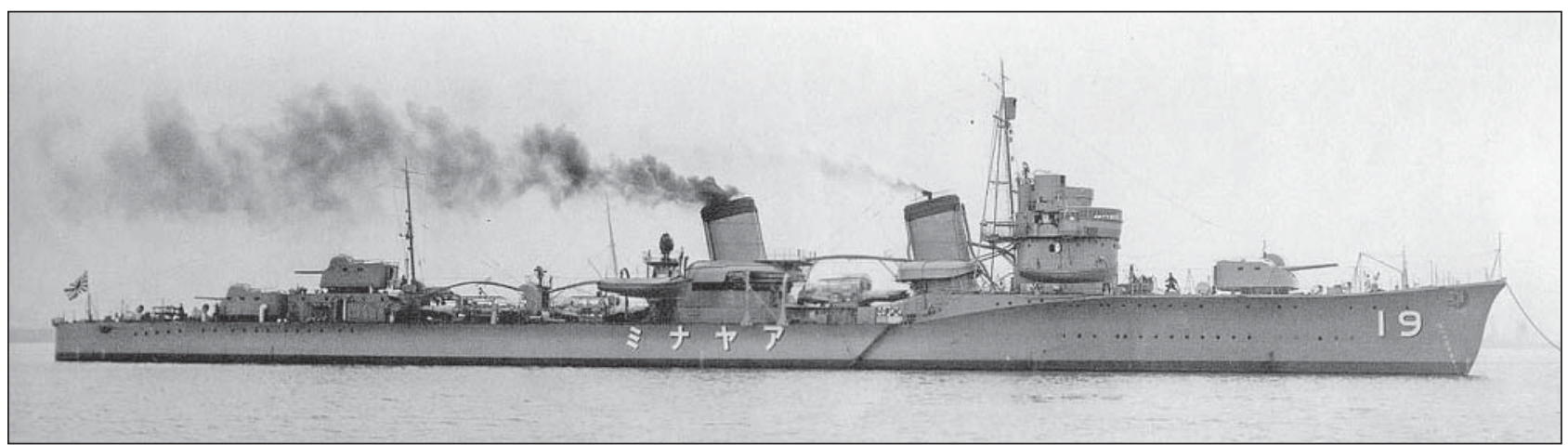




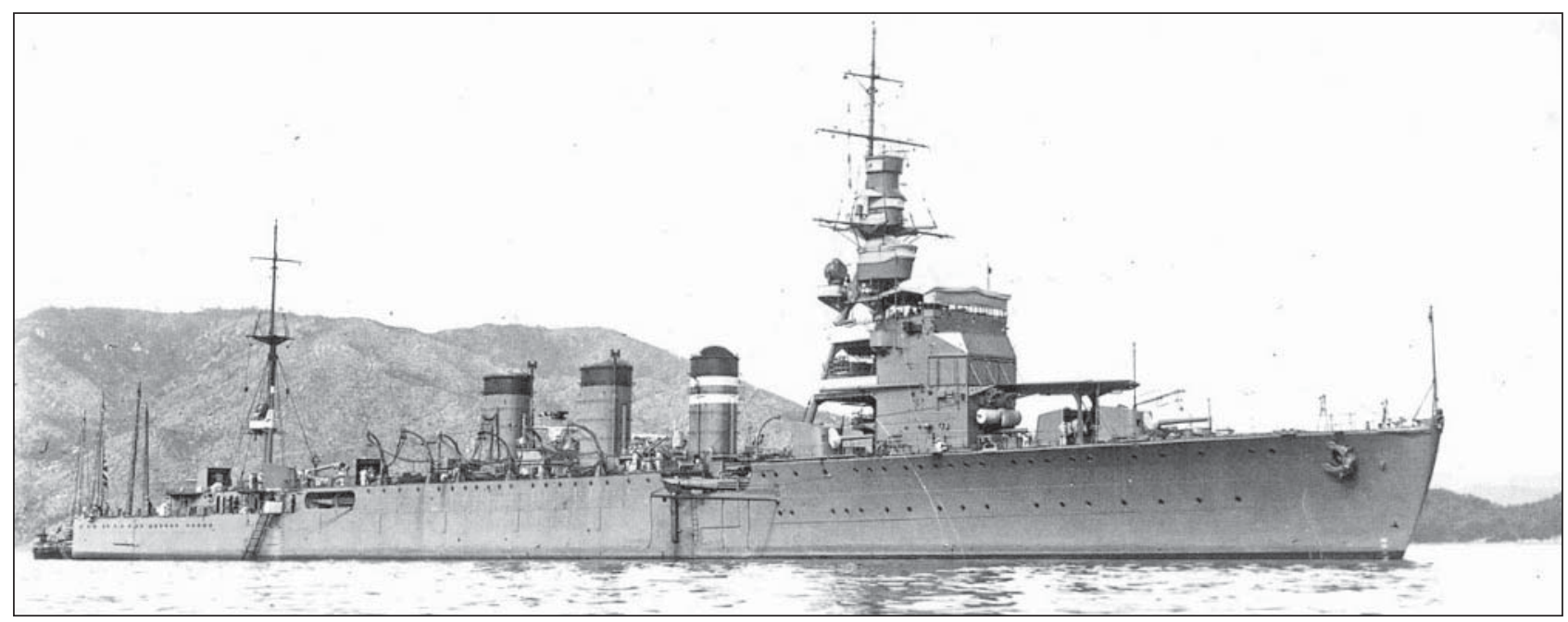

\section{8. ábra. A NAGARA könnyűcirkáló}

A japán haditengerészet éjszakai harcokban mutatott fölénye akkor kezdett olvadni, amikor az amerikaiak végre kezdték megtanulni, hogyan is kell használni a radarjaikat. A hajók egy része már addig is fel volt szerelve radarokkal, a parancsnokok azonban, akik semmilyen képzést nem kaptak a radarok használatáról, többnyire nem ismerték fel a készülék jelentőségét. Akadtak olyan kapitányok, akik hajójukon kikapcsoltatták a radart, abban a hiszemben, hogy annak jelzései nagyobb távolságról elárulják saját hajójuk helyzetét, mint ahonnan ők jelezni tudták az ellenségét. A tapasztalatlan, képzetlen, és gyakran fegyelmezetlen radarkezelők ügyetlenkedése szintén hozzájárult az addigi sikertelenséghez.

A radarok első eredményes használatára október 11-én éjszaka, az Esperance-foknál megvívott ütközetben került sor, amikor a Norman Scott ellentengernagy vezette amerikai hajóraj vereséget mért a repülötér bombázására készülő japán kötelékre, elsüllyesztett egy cirkálót és egy rombolót, több másik hajót pedig súlyosan megrongált. Az amerikaiak csupán egy rombolót vesztettek.

\section{Harcok Henderson Field térségében}

A növekvő veszteségek arra késztették a japán hadvezetést, hogy Henderson Field kiiktatására végre bevessék a flotta fő ütőerejének számító csatahajókat. A feladatra a flotta leggyorsabb, KONGO osztályú csatahajóit jelölték $\mathrm{ki}^{4}{ }^{4}$

9. ábra. Egy NAGARA osztályú könnyücirkáló parancsnoki hídja
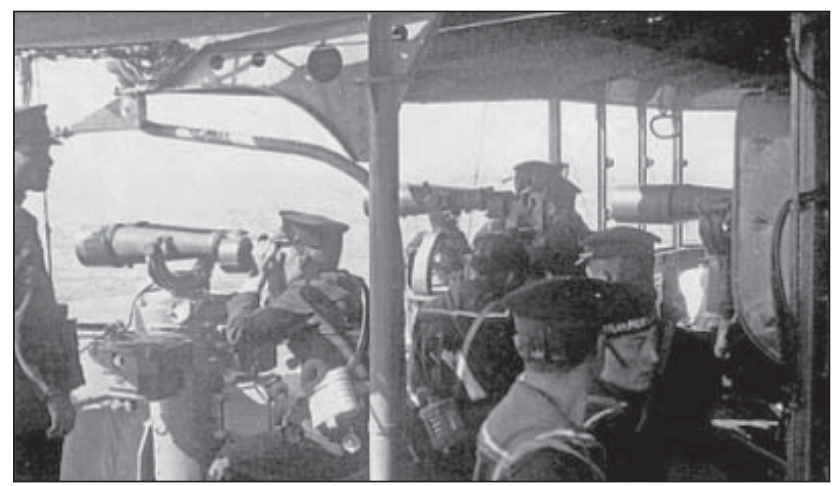

Az osztály első tagját, a 27500 tonnás KONGO-t, az angliai Vickers Múvektől rendelték meg, és 1913 augusztusában adták át a Császári Haditengerészetnek. Elkészültekor a hajót a világ legjobb és legerősebb csatacirkálójának tartották. ${ }^{5}$ Tervei alapján még további három hajó épült, de ezek már japán gyárakban.

A mintaként szolgáló brit csatacirkálókhoz hasonlóan a KONGO osztály páncélzata sem volt különösebben erős, vastagsága a vízvonalon legfeljebb $203 \mathrm{~mm}$, a lövegtornyoknál $254 \mathrm{~mm}$ volt. Ugyanakkor azonban, 64000 LE-s hajtómüveikkel a hajók sebessége elérhette a 27,5 csomót is.

A csatacirkálók fő fegyverzetét jelentő 356 mm-es löveg a japán haditengerészet egyik legmegbízhatóbb fegyvere

\section{0. ábra. A HIEI csatahajó szárazdokkban, 1941 novemberében}

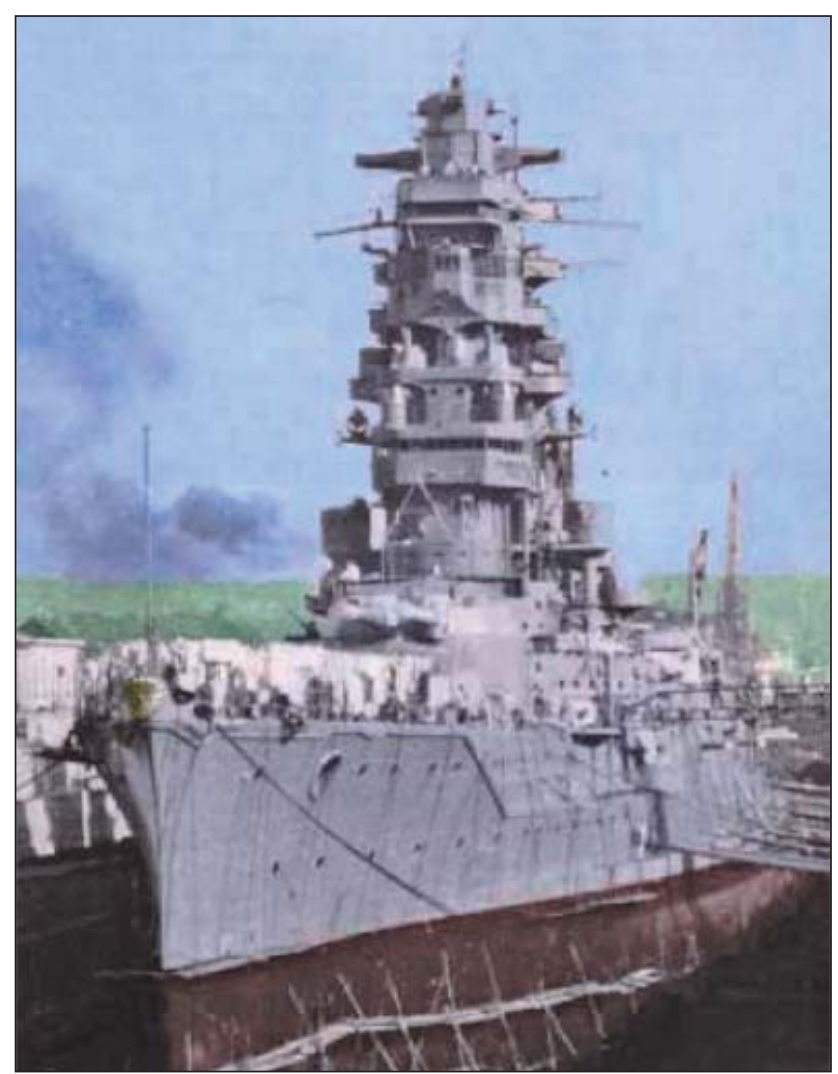




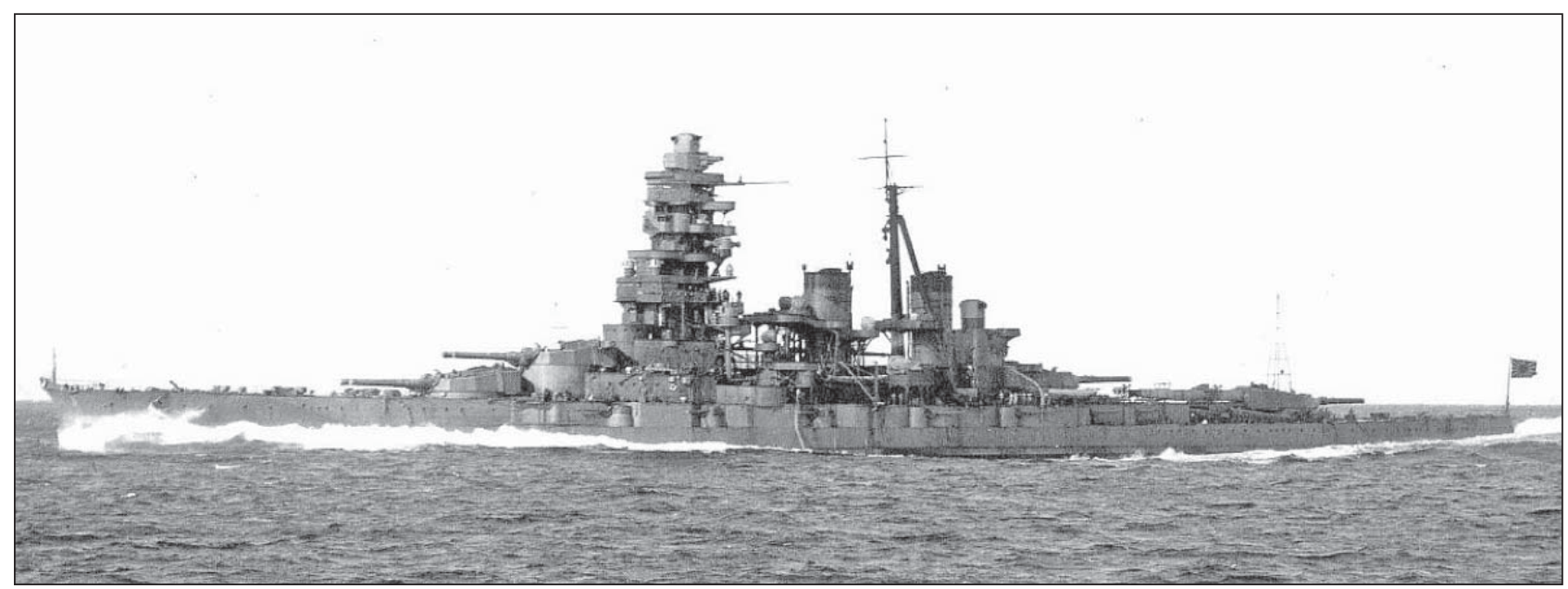

11. ábra. A HIEI csatahajó nyílt vízen, már átépített állapotban a II. világháború előtti években

volt. Az ágyú a $25^{\circ}$-os maximális csőemelkedés mellett, mintegy 25 kilométeres távolságra tudta kilőni a $635 \mathrm{~kg}$-os lövedékeket. A másodlagos tüzérséget a hajók oldalán, kazamatákban beépített $15 \mathrm{~cm}$-es kaliberű lövegek jelentették, amelyekből 16-ot helyeztek el a hajókon. A csatacirkálókat felszerelték nyolc darab, 533 mm-es torpedóvető csővel is.

A KONGO osztály egységeit az első világháború után többször is felújították és korszerűsítették, majd a harmincas években elhatározták teljes átépítésüket. Az átépítés fő célja az volt, hogy az osztály hajói képesek legyenek egy kötelékben hajózni a repülőgép-hordozókkal, és lépést tudjanak tartani azok 30 csomó körüli sebességével. Mindenekelőtt tehát a csatacirkálók hajtóműveinek teljesítményét kellett megnövelni. A széntüzelésű kazánok lecserélését már a húszas években elkezdték, a hajók ekkor részben áttértek az olajtüzelésre, ám mivel ugyanekkor a torpedóvédelem mélységét növelő rátétet is építettek a hajókra, sebességük a megnövekedett teljesítmény ellenére, mégis csökkent valamelyest.

$\mathrm{Az}$ átépítés során valamennyi régi kazánt eltávolították a hajókról, és a helyükre 11 darab olajtüzelésű kazánt építettek be, valamint újakra cserélték a gőzturbinákat is. Az olajtüzelésű kazánok teljesítményfölényét jól szemlélteti, hogy míg eredeti állapotában a hajóknak 36 széntüzelésű kazánra volt szükségük a 64000 LE teljesítmény eléréséhez, most 11 olajtüzelésű kazán ennek több mint a kétszeresét is biztosítani tudta, $s$ a hajtóművek összteljesítménye elérte a 136000 LE-t. A hajók vízkiszorítása az átépítések után mintegy 10000 tonnával lett nagyobb, ám az új, nagy teljesítményű hajtóművekkel sebességük így is elérte a 30,5 csomót.

Korszerűsítették a csatacirkálók fegyverzetét is, a lövegek nagyobb emelési szöget, és ezzel nagyobb lőtávolságot kaptak, a torpedóvetó csöveket pedig eltávolították a hajókról. A KONGO osztály páncélzatának komolyabb megerősítésére viszont nem volt lehetőség, csupán a fedélzeti páncélzat vastagságát tudták a régi páncélzatra szerelt új lemezekkel valamelyest megnövelni. Az átépítések után a hajókat hivatalosan is átminősítették csatahajókká. (A washingtoni 1922-es, majd a londoni 1934-es egyezmény megszűntette a csatacirkáló kategóriát, csak csatahajó lehetett. - Szerk.)

A háború kitörése után a KONGO osztály egységei váltak a japán haditengerészet legtöbbet foglalkoztatott csatahajóivá, ezek lettek a flotta igazi igáslovai. Nagy sebességük lehetővé tette, hogy közvetlen kíséretet adjanak a repülőgép-hordozóknak, így a háború szinte minden nagyobb hadműveletében részt vettek, míg a többi csatahajó az idő nagyobbik részét a hazai vizeken töltötte, a nagy, döntő ütközetre várva, amikor majd megmérkőzhetnek az amerikai csatahajókkal.

A háború azonban egészen más irányt vett, mint ahogy a konzervatív admirálisok várták. A nagy csatahajó ütközet elmaradt, helyette kisebb-nagyobb légi-tengeri összecsapások sorozatára került sor, amelyekben az egyre erősebb US Navy apránként farigcsálta szét a Császári Haditengerészet erejét.

A KONGO osztályú hajók korszerűsítése során a tűzvezetést is modernizálták, a parancsnoki tornyokat pedig megnagyobbították, hogy el tudják helyezni rajta az új tűzvezető

\section{2. ábra. A KIRISHIMA csatahajó 1937-ben, a második átépítés után}

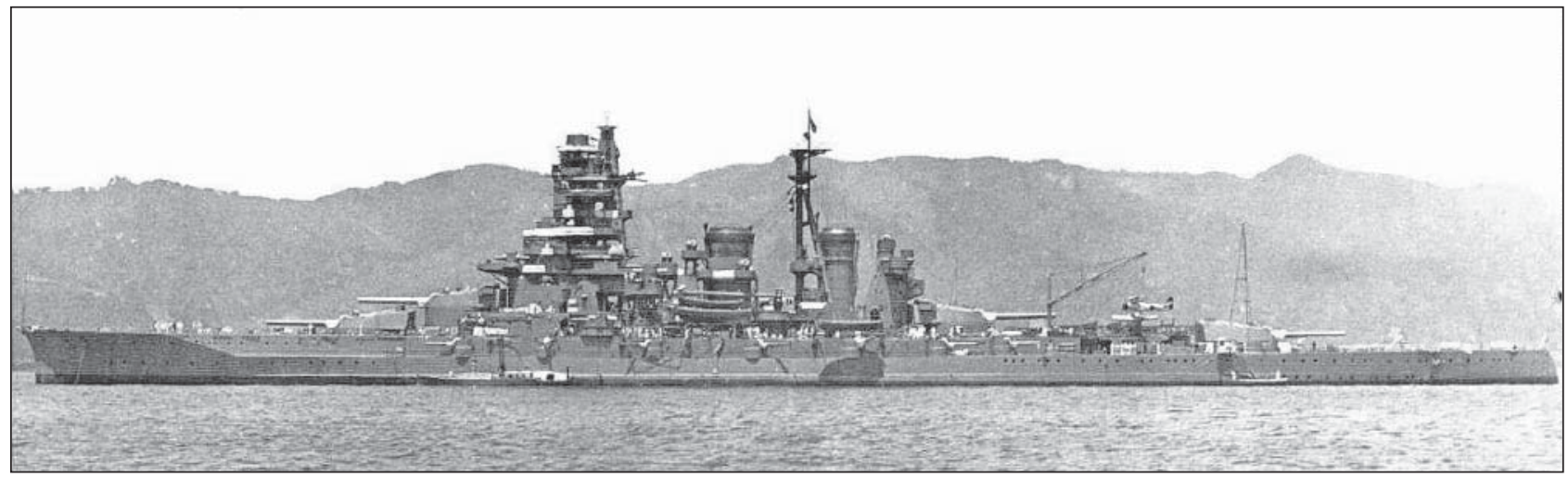




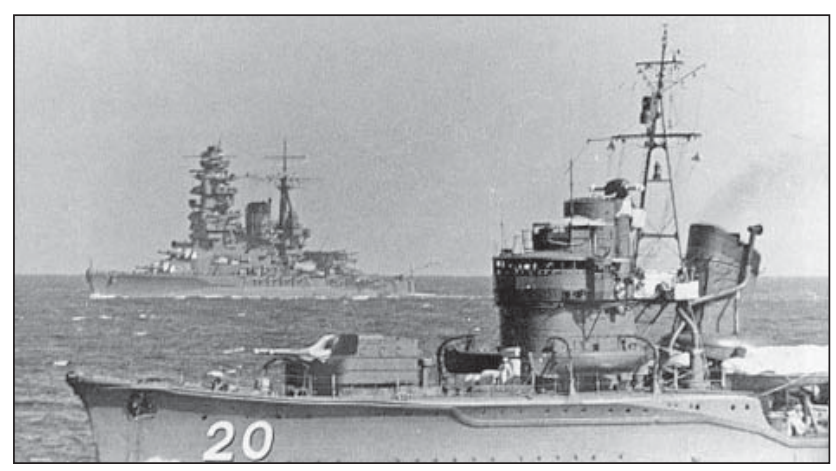

13. ábra. Egy japán romboló és egy KONGO osztályú csatahajó hadgyakorlaton

eszközöket. Ezek közül a tűzvezető eszközök közül viszont hiányzott valami, ami a harmincas évek végén pedig már minden nagyobb haditengerészet hajóin helyet kapott: a radar.

A radar hiánya nem a japánok technológiai elmaradottságát jelezte. A szakmájuk legjobbjai közé tartozó japán tudósok a harmincas években élenjártak a kutatásokban, és az angolokat évekkel megelőzve már 1936-ban létrehozták a mikrohullámú sugárzás előállítására alkalmas első magnetront. A haditengerészet és a hadsereg azonban teljes érdektelenséget mutatott a radartechnológia iránt.

A haditengerészet csak 1939-ben rendelte meg az első radarkészülékeket, de még ekkor sem katonai alkalmazásra, hanem navigációs segédeszközként, amelynek segítségével éjszaka és rossz látási viszonyok között is el lehetett volna kerülni a japán flottában gyakori összeütközéseket. Ennek megfelelően az új berendezés iránt a követelmény mindössze annyi volt, hogy néhány kilométeres távolságról legyen képes észlelni a közeledő hajókat. Az első ilyen radar már következő évben elkészült, de a flotta végül erre sem tartott igényt.

Az első, igazán használható japán radarok 1941 őszén készültek el, s a fontosabb kikötők és városok légvédelménél kerültek alkalmazásra. A berendezés kedvező esetben már 250 km-es távolságról képes volt észlelni a közeledő repülőgép-kötelékeket. Nagy mérete, és közel 9 t-s tömege miatt azonban, ez a készülék hajófedélzeti használatra nem volt alkalmas.

A haditengerészet hajói közül, 1942 áprilisában elsőként az ISE és HYUGA csatahajók fedélzetére kerültek radarok. Ezek még elég nehézkes és pontatlan készülékek voltak,

14. ábra. KONGO osztályú csatahajó korai állapotában, a szárazdokkban

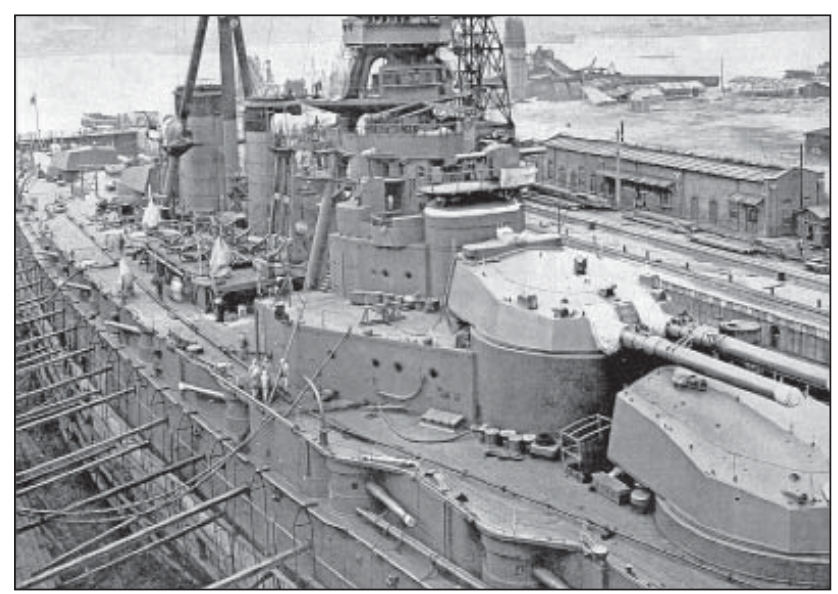

amelyek külön antennát használtak a jelek vételére és kisugárzására. Csak őszre készültek el az első olyan radarok, amelyek ugyanazzal az antennával tudták venni és adni a radarjeleket. A Type21Kai1 jelü radarok az év végén a csatahajók közül először a YAMATO és a MUSASHI fedélzetére kerültek fel. $A$ radar nem volt igazán nagy teljesítményü, a repülőgépeket mintegy 40 km-es távolságról, a nagy hajókat $30-35 \mathrm{~km}$-ről volt képes észlelni. A ké-

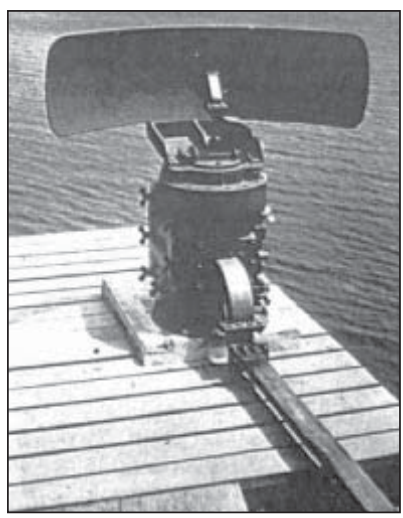

15. ábra. Az amerikai SG radar egyik prototípusa szülék elég pontatlan volt, alkalmatlan a tűzvezetés irányítására, ám felderítő eszközként a japán hajók így is nagy hasznát vehették volna. A radar azonban már túl későn készült el ahhoz, hogy a Guadalcanal körüli harcokban is alkalmazni tudják.

Yamamoto utasítására 1942. október 12-én a japán flotta Truk-nál állomásozó főerőiről leválasztották a HARUNA és KONGO csatahajókat, s egy cirkáló és három romboló kíséretében útnak indították őket Guadalcanal felé. A különítményhez másnap este még hat romboló is csatlakozott. A hajók észrevétlenül, ellenállásba nem ütközve közelítették meg Guadalcanal szigetét.

A HARUNA és a KONGO október 14-én éjjel fél kettőkor nyitott tüzet Henderson Fieldre, mialatt az ISUZU cirkáló a Tulagi-szigeten levő ütegeket támadta. A két csatahajó mintegy másfél óra alatt 918 darab 356 mm-es gránátot lőtt ki a repülőtérre, majd sértetlenül visszavonultak.

A csatahajók elsősorban az eredetileg légvédelmi célokra kifejlesztett Type 3 IS repeszgránátokat használták, amelyek a vártnál is hatékonyabbnak bizonyultak a szárazföldi célpontok ellen. Csak miután ezeket a gránátokat elhasználták, tértek át a páncéltörő AP gránátokra, amelyek viszont már közel sem voltak olyan hatásosak. A pusztítás így is hatalmas volt, megsemmisült a repülőgépek több mint fele, szinte a teljes üzemanyagkészlet, és súlyos károkat szenvedett maga a repülőtér is. Az ellenséges légierő átmeneti meggyengülését kihasználva egy japán konvoj aznap éjszaka sértetlenül elérte Guadalcanalt, és bár másnap a megmaradt amerikai gépek súlyos veszteségeket okoztak a hajóknak, rakományuk nagyobbik részét addigra már sikerült kihajózniuk. A következő éjszaka két japán cirkáló is ágyúzta a repülőteret, de közel sem tudtak akkora károkat okozni, mint a csatahajók.

A végre jelentős erősítéseket kapott japán csapatok október 23-án indították meg a döntőnek szánt támadást, azonban ezúttal is több irányból támadtak, erőiket szétaprózva, és súlyos vereséget szenvedtek. Néhány nappal később a japán flotta főerői is újra támadásba lendültek, abban bízva, végre sikerül csapást mérniük az amerikai flottára, és kimozdíthatják a holtpontról a Guadalcanal körüli harcokat. Az október 26-án, a Santa Cruz-szigetek mellett megvívott tengeri ütközetben Yamamotonak ugyan sikerült vereséget mérnie a William Halsey altengernagy vezette amerikai kötelékre, ám a csatában a japán repülőgép-hordozók repülőgép-állománya is olyan súlyos veszteségeket szenvedett, hogy az ütközetet követően ők is kénytelenek voltak visszavonulni. (A csatában súlyosan megsérült a ZUIHO, könnyebben a SHOKAKU hordozó, illetve a CHIKUMA cirkáló. Ezek repülőgépei önfeláldozó módon bombázták a CV-8 HORNET hordozót, amelyet 


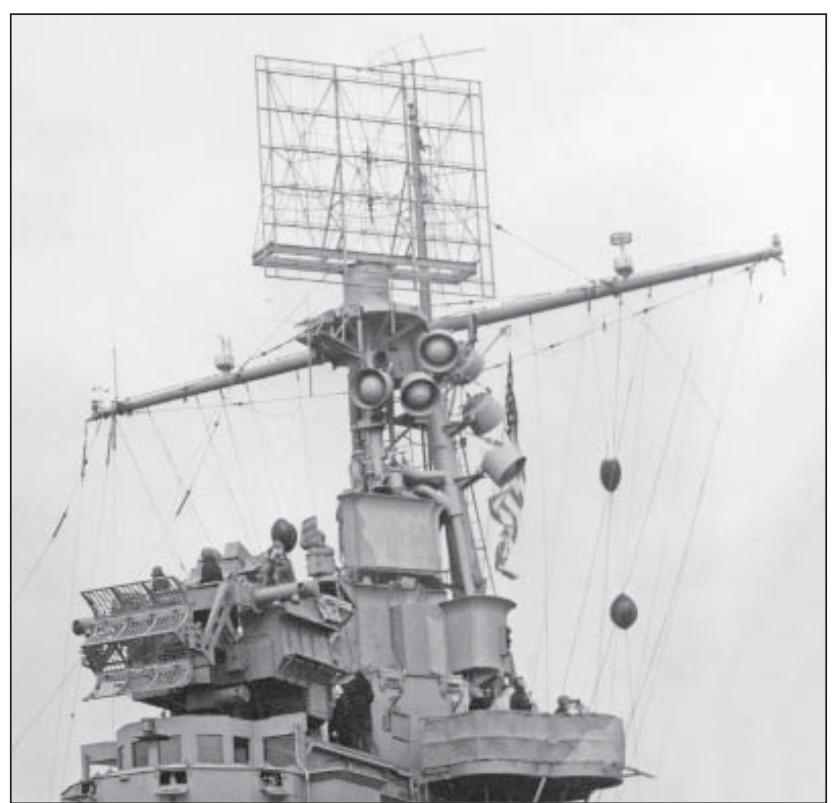

16. ábra. Amerikai CXAM radar antennája egy amerikai repülőgép hordozón

később két japán romboló elsüllyesztett. Megrongálták a CV-6 ENTERPRISE hordozót, a SOUTH DAKOTA csatahajót és a SAN JUAN cirkálót. - Szerk.)

A Guadalcanal körüli harcok ekkor még mindig kiegyenlített küzdelemnek számítottak. A szárazföldön a japánok nagy veszteségeket szenvedtek ugyan, de még mindig tartották magukat a szigeten, és változatlanul fenyegették az ottani amerikai erőket. A tengeri harcok váltakozó sikerrel folytak, de alapvetően a japánok szerepeltek jobban. A két fél veszteségei nagyjából egyenlőek voltak. Ez az egyenlőség azonban az amerikaiaknak kedvezett, a japánok nem bírhatták olyan sokáig ezeket a veszteségeket, mint ők. Ezzel a japán hadvezetés is tisztában volt, ám ennek ellenére még mindig nem akarták feladni a harcot, és újabb támadást készítettek elő.

A japánok alapjában véve az október 14-i akciót akarták megismételni. Yamamoto november kilencedikén ezúttal a HIEl és a KIRISHIMA csatahajókat vezényelte Guadalcanalhoz, Abe Hiroaki altengernagy parancsnoksága alatt. A két csatahajót a NAGARA cirkáló, és tizenegy romboló kísérte.
Az amerikaiak észlelték a japán előkészületeket, és maguk is erősítést juttattak el csapataikhoz. A teherhajók kirakodását biztosító öt cirkáló és nyolc romboló a Guadalcanal északi csúcsánál fekvő Savo-sziget környékén járőrözött. A már tapasztalt veteránnak számító Norman Scott ellentengernagytól a nemrég érkezett Daniel Callaghan ellentengernagy vette át a kötelék parancsnokságát, mivel szolgálati ideje három nappal hosszabb volt, tehát ő számított a rangidős tisztnek. Callaghan azonban teljesen tapasztalatlan volt az éjszakai harcokban, és a radar használatában.

Noha már az amerikai hajóraj öt hajója is fel volt szerelve a legújabb SG radarokkal, Callaghan mégsem ezeket állította a kötelék élére, és nem is ilyet választott zászlóshajójának, hanem a csak egyetlen légtérfigyelő radarral felszerelt SAN FRANCISCO nehézcirkálót. A tengernagy ráadásul nem adott semmilyen utasítást beosztott parancsnokainak, és nem dolgozott ki semmilyen csatatervet, noha a felderítés már előző délután észlelte a közeledő hajókat, és az amerikaiak tudhatták, hogy újabb összecsapásra lehet számítani.

\section{(Folytatjuk)}

\section{ForRÁs}

\section{U.S.NAVAL RESEARCH Laboratory: Development of} the Radar Principle, https://www.nrl.navy.mil/ accomplishments/systems/radar/. Letöltés 2017. Július 23.;

2. Norman Friedman: Naval radar; Naval Institute Press, 1981.;

3. Norman Friedman: U.S. Battleships: An illustrated design history; Naval Institute Press, 1985.;

4. William Garzke-Robert Dulin: Battleships: United States Battleships, 1935-1992; Naval Institute Press, 1995;

5. Mark Stille: USN Cruiser versus IJN Cruiser, Osprey, 2009.;

6. Lawrence Burr: US Fast battleships, 1936-1947; Osprey, 2010.

7. Masataka Chihaya-Yasuo Abe: IJN Kongo, Battleship 1912-1944; Profile Publications, 1971http://www. navweaps.com/;

8. http://importanceofelectronics.blogspot.lu/2009/06/ history-of-radar.html.

\section{JEGYZETEK}

1 Taylor 1922-ben született ötlete igazából még nem a későbbi radarokról szólt. Egyszerűen csak arról volt szó, hogy elképzelése szerint a flotta előtt járó rombolók éjszaka egymástól több mérföldes távolságban, csatárláncban sorakoztak volna fel, és az egymás felé küldött jelek visszaverődése elárulta volna, ha két romboló között ismeretlen hajó próbált volna áthaladni. Az ötletet elbíráló bizottság azonban azt nem találta a gyakorlatban is megvalósíthatónak.

2 A német kutatók nagyjából ugyanekkor láttak hozzá saját mikrohullámú készülékeik fejlesztéséhez, miután azonban a kutatások nem ígértek egy éven belül kézzelfogható eredményeket, Hitler leállította ezt a fejlesztést is. A németek később a területeiken lezuhant, radarokkal felszerelt angolszász repülőgépek roncsaiból próbáltak meg egy használható mikrohullámú radarkészüléket összeállítani, ami azonban már csak a háború végére sikerült nekik.

3 A Guadalcanal körüli harcokban csak cirkálók és rombolók vettek részt. A főerők csak távolsági fedezetet adtak, a csatahajókat és repülőgéphordozókat mindkét fél óvakodott bevetni a szigetek közelében, ahol a tengeralattiárók és repülők komoly fenyegetést jelentettek. A harcok során a Savo-sziget és Guadalcanal közötti szorosban olyan sok amerikai és japán hajó süllyedt el - a harcok végéig összesen több mint ötven -, hogy a tengerészgyalogosok elnevezték Acélfenekű Szorosnak.

4 Szeptembertől már Trukon állomásozott a YAMATO, a világ legnagyobb csatahajója is, amelyet azonban a japánok végül nem vetettek be a Guadalcanal körüli harcokban. A parancsnokság túlzottan is féltette a döntö ütközetre tartogatott, értékes hajót, amelynek ágyúihoz ráadásul nem volt olyan lőszer, ami a szárazföldi célpontok lövetésére alkalmas lett volna.

5 A török csatahajó-vásárlásokat ellensúlyozni akaró görög haditengerészet még az építés befejezése előtt ajánlatot tett a KONGO megvásárlására, amit a japán vezetés nem fogadott el. Később, már a háború alatt, a brit haditengerészet szerette volna bérbe venni a japánoktól négy csatacirkálójukat, ők azonban ezt a kérést is elutasították. 